\title{
The Structure of Humor in Psycho Stand-Up Comedy by Margaret Cho
}

\author{
Anindita Dewangga Puri \\ English Letters Department, Universitas Sanata Dharma, Yogyakarta \\ aninditapuri@usd.ac.id
}

Riwayat Artikel: Dikirim 15 Februari 2020; Diterima 12 Juni 2020; Diterbitkan 30 Juni 2020

\begin{abstract}
This research aims to analyze the structure of humor in Psycho stand-up comedy employed by Margaret Cho. It is qualitative descriptive research. The main source of this research is the oral data in Psycho stand-up comedy performed by Margaret Cho. There are three steps to find out the aim of this research: the data collection from stand-up comedy entitled Psycho, the analysis of the data, and the last is the display of the result. After all of the data is collected, the researcher tries to find out the structure of Psycho standup comedy by using the sequence of joke theory by Rutter and the structure theory of stand-up comedy by Scarpetta and Spagnolli. Based on the data analysis, the researcher finds that this stand-up comedy is divided into three parts: the opening, the core, and the closing. A master of ceremony conducts the opening. The body of this stand-up comedy consists of 31 bits, and in one bit, there are parts such as setup, transition, punchline, act-out, and expanding successful jokes. Margaret Cho delivers the closing of this standup comedy as an appreciation to her audiences. The researcher also finds that the punchline that is done repeatedly becomes the characteristics of Psycho stand-up comedy employed by Margaret Cho.
\end{abstract}

Keywords: stand-up comedy, humor, discourse, Margaret Cho, pragmatics

\begin{abstract}
ABSTRAK
Penelitian ini bertujuan untuk menganalisis struktur bumor dalam stand-up comedi berjudul Psycho yang disajikan oleh seorang comedian bernama Margaret Cho. Penelitian ini merupakan penelitian deskriptif kualitatif. Sumber data utama dari penelitian ini adalah data lisan dalam stand-up comedy Psycho. Penelitian ini dilakukan melalui tiga langkah. Pertama adalah tahap pengumpulan data dari stand-up comedy Psycho, tahap kedua adalah analisis data, dan tahap terakhir adalah penyajian hasil analisis data. Setelah semua data terkumpul, data-data tersebut dianalisis menggunakan teori sequence of joke oleh Rutter dan teori tentang struktur stand-up comedy oleh Scarpetta dan Spagnolli. Berdasarkan hasil analisis yang telah dilakukan, peneliti menemukan vahwa
\end{abstract}


stand-up comedy berjudul Psycho ini dibagi menjadi tiga bagian: bagian pembuka, bagian inti, dan bagian penutup. Bagian pembuka dilakukan oleh seorang pembawa acara. Bagian inti dari stand-up comedy ini terdiri dari 31 bit, di mana pada setiap bit terdapat beberapa bagian yang dimunculkan seperti setup, transition, punchline, act-out, dan expanding successful jokes. Bagian penutup dari stand-up comedy ini disampaikan sendiri oleh Margaret Cho sebagai ungkapan apresiasi dan terima kasih bagi para penontonnya. Pada penelitian ini, ditemukan pula punchline yang dilakukan secara berulang-ulang, di mana hal ini menjadi ciri khas dari stand-up comedy Psycho yang disajikan oleh Margaret Cho.

Kata kunci: stand-up comedy, lelucon, wacana, Margaret Cho, pragmatik.

\section{INTRODUCTION}

As part of human life, humor has a function to reduce the tension in the human mind. Ross (2005), in his book, said that humor is everything that makes people laugh. Producing humor is one of the human abilities. One of the sense of humor that is produced by human ability is stand-up comedy. According to Double (2014), stand-up comedy happens when a comedian acts in front of the audience by telling something funny. A comedian or a comic amuses the audience through his or her jokes on the stage.

Stand-up comedy first came up in the $19^{\text {th }}$ century in America and Europe. America becomes a pioneer of famous omics such as Robin Williams, Sarah Silverman, Christ Rock, Ellen Degeneres, and Margaret Cho. Each comic has its characteristics in delivering the comedic material, for example, Christ Rock, whose jokes related to politics, race, and celebrities. Ellen Degeneres, whose jokes have topics related to gay and lesbian. Margaret Cho, whose jokes related to racism, women, and sexual behavior.

In this research, the researcher chooses the stand-up comedy employed by Margaret Cho. She is a famous stand-up comedian woman from America. The comedic material from Margaret Cho tends to have a relation toward women, racism, politics, or sexual behavior. Sometimes Cho is also mocking the Asian in her stand-up comedy (Chun, 2004). Moreover, according to Yus (as cited in Attardo, 2017), sometimes the comedian or the comic uses a typical social issue such as profession or sex-role stereotypes as the material on his or her stand-up comedy according to the personal beliefs of the audience. In conducting this research, the researcher chooses one of the stand-up comedy videos of Margaret Cho that is Psycho. It is a stand-up comedy that was held in 2015. This stand-up comedy consists of the jokes material, which is related to the madness and the anger of Margaret Cho, such as the feeling of Cho when she saw the action of police brutality, racism, and also the increase of the violence against the women. Margaret Cho tries to deliver her madness and feeling through the humor. 
This research is a small part of the thesis that had been done by the researcher. It examines discourse analysis because the sentence related to one another. As what Moeliono (as cited in Mulyana, 2005) said that discourse is a sentence which has relation from one to another in the unity of meaning. It is categorized as the complete language unit in the language hierarchy. Discourse analysis is used the language units by looking at the existing context because it is essential to understand the context to know the meaning that exists in a text. In analyzing the discourse, the researcher uses a pragmatic approach to understand the linguistic context. It is because in analyzing the elements in a discourse, the researcher has to understand the meaning of what is said by the speaker and also to learn on how speakers organized what they want to speak to the hearer (Yule, 1996).

Several important things need to be considered in analyzing a discourse. According to Littlejohn (as cited in Sobur, 2006), we need to pay attention to the structure that makes a discourse becomes coherent, the aims of the utterances, and the principles used in the discourse. Therefore, it is important to understand the structure of Psycho stand-up comedy discourse to observe its regularity.

This research takes female stand-up comedian as an object because it is still only a few studies that examined the stand-up comedy employed by a woman, especially in terms of linguistics. Moreover, a sequence of the jokes and also the interactional development between the comedian and the audience are commonly discussed in the research of humor (Rutter, 2000). That is the reason why the researcher conducted this research. It focuses only on the structure of the humor discourse in Psycho stand-up comedy by Margaret Cho. Research on stand-up comedy presented by a female comic is still minimum, and it is because the point of view that men are more able to create a humorous situation rather than women.

In conducting this research, the researcher provides several previous types of research related to stand-up comedy to support this research. First, the study from Triandana (2014) entitled "Analisis Wacana Humor dalam Film Kill the Messenger (Studi Kasus Stand-up Comedy Christ Rock)". One of the aims of this research is to find out the structure of humor discourse in the Kill the Messenger film. The result of the study found that there are various structures and patterns in the Kill the Messenger film that can create a humorous situation, they are one-liners, questions and answers, simple structures, and complex structures. The second research was conducted by Afidah \& Wahyudi (2014) entitled How It Starts and Ends: A Study of Indonesian Stand-Up Comedy. This research analyses the opening and the closing of the stand-up comedy employed by Raditya Dika, Ryan Adryandhi, and Abdel Achrian as the Indonesian comedians, compared with the Rutter's (1997). As a result, the researchers found that the opening and the closing of those stand-up comedies have similarities with Rutter's pattern.

The third research entitled $A$ Comparison Malaysian Ethnic and Political Stand-up Comedies' Text Structures and Use of Politeness Strategies (Onn, 2018). One 
of the aims of this research is to investigate and compare the text structure of ethnic and political Malaysian stand-up comedies by using Hockett's (1960) internal structure of jokes. Here, the researchers found that the two comedians used three standard structures of stand-up comedy: build-up, pivot, and punchline. However, the use of build-up is more in ethnic jokes rather than political jokes. It is because of the characteristic of ethnic standup comedy where the comic needs to specify the target stereotype to avoid generalization.

This research is different from previous research. The researcher tries to focus on stand-up comedy by a woman because the research on stand-up comedy that is presented by female comic is still minimal, it is because the point of view that men are more able to create a humorous situation rather than women. This research was also combining the theory of humor structure by Rutter (1997) and Scarpetta \& Spagnolli (2009) so that it can be seen in its regularity.

\section{THE STRUCTURE OF STAND-UP COMEDY}

Rutter (2000) identified the sequence of the stand-up comedy, which was held by stand-up comedy from the English year 1990. It consists of opening by a compere or a master of ceremony, followed by the comedian entrance, the body of the show, and the last is the closure. There are several parts of opening in stand-up comedy (Rutter, 1997). First is contextualization in which the compere or the host introduces the background of the stand-up comedy. Second is a framing of response; the host gives a clue to the audience to perform an action when the comedian is arriving. The third is the evaluation of the comedian in which the host mentions the positive and the negative sides of the comedian. The last is a request for action, that is the technique of the host to invite the audience to give a contribution to that even. Generally, the host will say, "please welcome," and the applause of the audience will follow it.

Closing is also an essential part of stand-up comedy. According to Rutter (1997), there are some structures of closing in the stand-up comedy:

a. Pre-closing which is characterized by a few things that the comedian did to show that the stand-up comedy is almost complete.

b. Audience laughter in which the audience laughs after the pre-closure. The audience's laughter is the sign that the comedian is successful in delivering the material.

c. Comment on the audience is the opportunity of the comedian to comment on the audience.

d. Re-introduction. In this part, the comic or comedian reintroduces his or her name.

e. Appreciation is one of the parts when the comic or comedian appreciates the audience. 
f. Exclamatory closing usually done before the comedian leaves the stage.

g. When the comedian leaves the stage, it is continued by the applause from the audience.

h. Compere's outro is the last part of closing by the host after the comedian leaves the stage.

Specifically, Scarpetta \& Spagnolli (2009) divide the structure of the standup comedy into some parts:

a. Starting the interaction. In this part, the audiences give applause to welcome the arrival of the comic or comedian. In general, the comedian will react to the audience and says thank you to the audience.

b. Transition to a new joke sequence. Here, the joke materials are delivered by the comedian. A move between a joke to other jokes is required here. The comedian must be able to take the audience from one bit to another bit by using some transitions; they are fillers and surveys. The filler is usually located after the punchline. It is meaningless and is not a part of a new bit. Furthermore, surveys happen directly before the next punchline.

c. Expanding successful jokes. The comedian or comic can improve another punchline repeatedly in his or her stand-up comedy.

d. Referring to the audience in the punchline. In this part, the comic or the comedian presents a punchline to make the audience laugh.

\section{METHOD}

This research is descriptive qualitative research. It included the data collection, the analysis, the interpretation, and report writing. The qualitative research is conducted by using purposeful sampling, analysis of text or pictures, interpretation information in figures or tables, and personal interpretation of findings (Creswell, 2014). The researcher chose Psycho stand-up comedy as the object of the research and downloaded the stand-up comedy video at https://www.youtube.com/watch?v=_VfOZCm92Yg, which was uploaded by Menard (2017). There are three steps to doing this research. The first step is data collection. In this step, the researcher observed all the utterances in Psycho stand-up comedy employed by Margaret Cho. All the data were transcribed according to the subtitle. After that, the researcher divided the data into three parts: the opening, the body, and the closing and also gave a number on each sentence to make easy the analysis.

The second step is data analysis. The data is classified into a table that is filled by some description and classification. The researcher also observed the punchline, which made the audience laugh. At the same time, the researcher observed the expression of Margaret Cho when she was delivering the stand-up comedy material. This discourse has one premise, and this premise consists of several bits. The researcher used the contextual method to determine the bits. 
The last step is the display of the result. Here, the researcher uses formal and informal methods. The data were written into the table form by using a formal method. Moreover, the descriptions of the analysis were written by using the informal method.

\section{FINDINGS AND DISCUSSIONS}

Here is the structure of the Psycho stand-up comedy. The researcher gives some examples as a representation of overall data analysis.

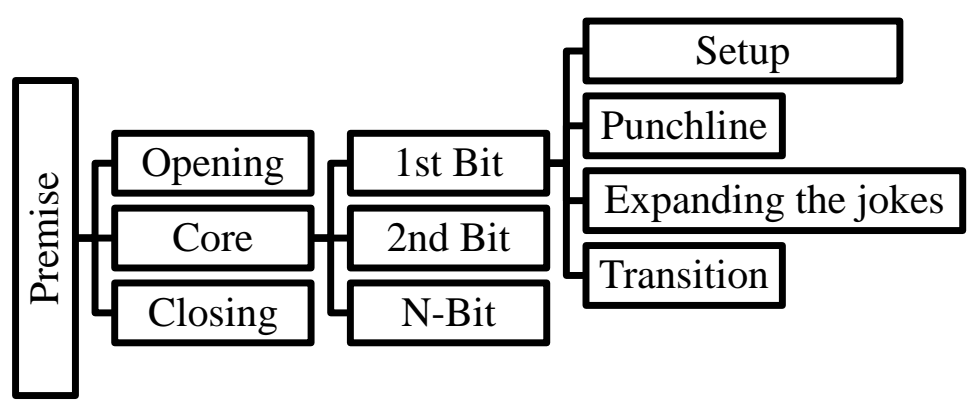

\section{Introduction}

The introduction is the earliest part of a stand-up comedy. According to Rutter (1997), the host opens the stand-up comedy and is followed by applause from the audience. According to the transcript of Psycho stand-up comedy, the introduction is started by the host who says, "please welcome, Margaret Cho!" and then the audiences give applause until Cho stands into the stage. The host in the stand-up comedy applies one of the opening stages to accompany the entry of the comedian by request for action because he asks the audience to give appreciation to the presence of the comedian that will convey the comedy material on the stage.

\section{Starting the Interaction}
1 Thank you!
2 Oh, my gosh.
3 Thank you.
4 Thank you so much.
5 Thank you.
6 I love you.
7 Thank you so much for coming.
8 This is exciting. We're filming. (audiences' applause and cheering quiets)

According to the data analysis, the next step after the introduction is starting the interaction (Scarpetta \& Spagnolli, 2009) from a comedian or a comic on the stage to the audience. It also is known as the comedian entrance, as Rutter 
(1997) stated. There is a reciprocal happening between Margaret Cho and her audience. After the audiences give applause and cheers to Cho at the opening, Cho responses by saying, "Thank you! Thank you so much! I love you! Thank you! Thank you so much! I love you!" as a form of appreciation toward the audiences' reaction.
9 So... where's the Asian people?
10 Where's the Asian people?
11 Where's the... oh, thank God!
12 No, I know, 'cause I-I know, it's...
13 I see and I know you had to drive. (laughter)
14 So I'm so glad, it's dangerous.
15 Thank you for coming.

The data above is still part of starting the interaction. This is a transition which is done by Margaret Cho by giving question to the Asian audience. It aims to attract audiences' attention so that they will be a focus on receiving the comedy material.

\section{The Body of the Show}

This part is the core of the stand-up comedy material which is delivered by the comedian. There are several bits in the Psycho stand-up comedy wherein each bit has a section structure such as setup, punchline, expanding successful jokes, and transition to a new joke sequence. Here is one of the example:

(Bit 1)

Tabel 1:

Data penelitian

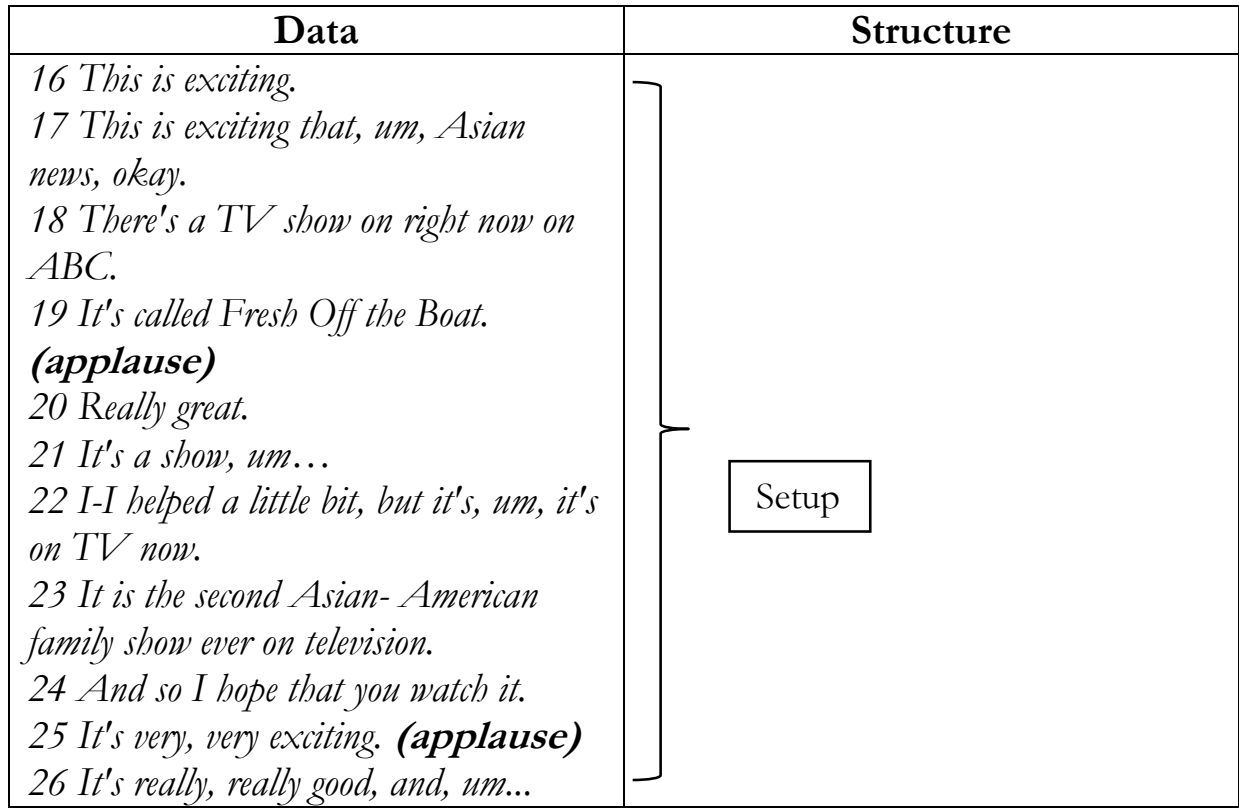




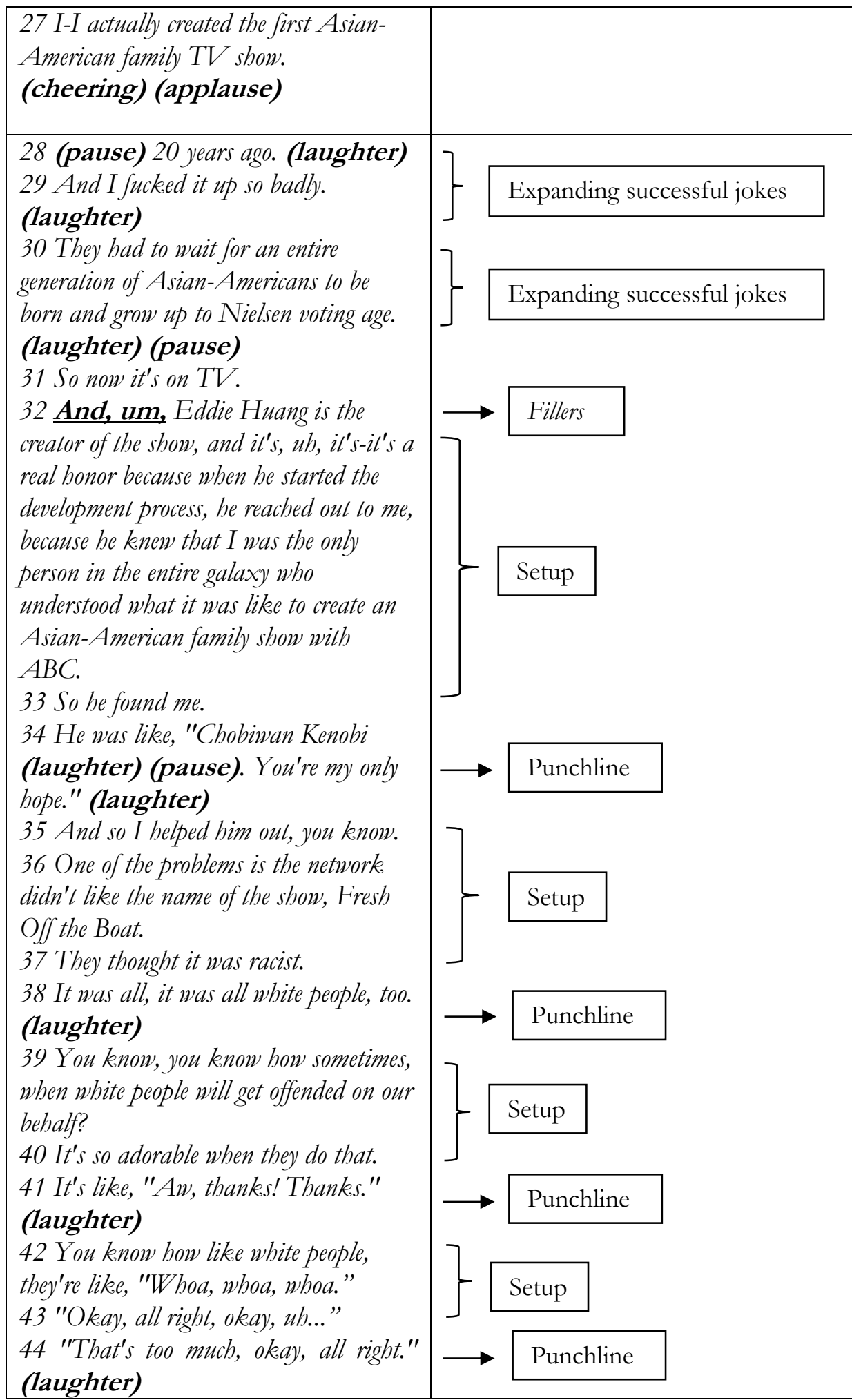


According to the data analysis, it can be seen that there is some part, such as setup, punchline, fillers, and expanding successful jokes. Margaret Cho uses setup or introduction as a starting point to convey the comedy material, and this part is not to laugh at. Furthermore, the punchline is a surprise part that makes the audience laugh. The transition with fillers strategy is used by Margaret Cho after a punchline to take the audience into the next joke in the same bit. A successful expanding joke is repeated by Cho to take the audience to the climax.

\subsection{Setup}

According to (Dean, 2000), setup is the first part of jokes, and it has a function to set up the laugh for the audience. Setup is the earliest part where the comedian explains the context of his/her utterance to the audience. This part is not funny, and it is not to laugh. It gives the audience the idea of the comedy material presented by the comedian.

\section{(Bit 1)}

16 This is exciting.

17 This is exciting that, um... Asian news, okay.

18 There's a TV show on right now on $A B C$.

19 It's called Fresh Off the Boat. (applause)

20 Really great.

21 It's a show, um...

22 I-I helped a little bit, but it's, um, it's on TV now.

23 It is the second Asian-American family show ever on television.

24 And so I hope that you watch it.

25 It's very, very exciting. (applause)

26 It's really, really good, and, um...

27 I-I actually created the first Asian-American family TV show.

(cheering) (applause)

28 (pause) 20 years ago. (audience laughs)

The setup from bit 1 starts from the data number 16 to 27 . Margaret Cho tells the first Asian-American family TV show starring herself. The topic that is delivered by Margaret Cho aims to create an image of the audiences for what is said by Margaret Cho. This part is not funny at all, but it can bring up things like applause and cheers from the audiences.

\subsection{Punchline}

The punchline is a part of a joke that can cause a laughing effect for those who hear it. The setup part of the jokes gives the audience a story that comes in their minds to expect something (Dean, 2000). After that, the comedian provides the punch surprises to make the audience laugh.

(Bit 1)

16 This is exciting.

17 This is exciting that, um... Asian news, okay. 
18 There's a TV show on right now on $A B C$.

19 It's called Fresh Off the Boat. (applause)

20 Really great.

21 It's a show, um...

22 I-I helped a little bit, but it's, um, it's on TV now.

23 It is the second Asian-American family show ever on television.

24 And so I hope that you watch it.

25 It's very, very exciting. (applause)

26 It's really, really good, and, um...

27 I-I actually created the first Asian-American family TV show.

(cheering) (applause)

28 (pause) 20 years ago. (audience laughs)

In this first bit, Margaret Cho gives her first punchline on sentence number 28. Before that punchline comes up, Cho tells about one of her TV shows entitled Fresh Off the Boat starring by herself. She also adds that she had played the first Asian-American family TV show. In the audiences' mind, Cho may have just made the TV show in just a few years. In fact, after a short break that is created, Margaret Cho immediately says that she actually starred that TV show 20 years ago, and it was a very long time ago. This is what makes the audience laugh out loud after that.

\subsection{Transition to a New Jokes Sequence}

Transition to a new joke sequence is the part of the core where a comedian is expected to be able to set the movement from a joke to other jokes. According to the data collection, this stand-up comedy uses more fillers to set the movement of the jokes. Fillers have a function to connect one joke to another joke in the same bit.

(Bit 1)

27 I-I actually created the first Asian-American family TV show.

(cheering) (applause)

28 (pause) 20 years ago. (laughter)

29 And I fucked it up so badly. (laughter)

30 They had to wait for an entire generation of Asian-Americans to be born and grow up to Nielsen voting age. (laughter) (pause)

31 So now it's on $T V$.

32 And, um, Eddie Huang is the creator of the show, and it's, uh, it's-it's a real honor because when he started the development process, he reached out to me, because he knew that I was the only person in the entire galaxy who understood what it was like to create an Asian-American family show with $A B C$.

33 So be found me. 
The data above shows the use of fillers as they transition to move into another joke in the same bit. The word and, um do not have any specific meaning, but it has a function as a sign to move towards other jokes in a bit.

In addition to fillers, Margaret Cho also uses surveys as they transition to another joke. $A$ survey is a term on how a comedian involves the audiences directly before entering the next jokes. Here is the example of transition, which is to use surveys in Psycho stand-up comedy.

(Bit 20)

620 I do... I do really love the sex toys thing, but if you keep using them, you will get addicted, you do.

621 You... vi-vibrator fans?

622 You like vibrator...?

623 It's fun.

624 What kind of vibrator do you have? (gasping, laughter) (laughter)

625 Why?

626 Woman: I like the Magic Wand.

627 Oh, the Magic W and is the best! (whooping)

628 The Magic $W$ and is really, really...

629 The Magic Wand, it's, like, really... (imitates vibrator)

630 The Magic W and is solid, because, you know, it-it will last for a long

time, and, you know, it's not, like, a confusing vibration.

631 Like, the vi... vibrator that makes me confused is the Rabbit.

632 Cause the Rabbit is like this, but then it's also like this. (laughter)

According to the bit 20, Margaret Cho uses surveys as the transition to get into the new joke. Cho tries to interact with one of the female audiences about the sex toy that Cho likes. That is discussed on the utterances number 620 until 626. Up to number 627 until 632, the joke that is discussed is no longer about the vibrator but rather more specific to the magic wand vibrator.

\subsection{Expanding Successful Jokes}

In this part, a comedian gives multiple punchlines at one in the same bit. The more a comedian can bring up the punchline, the more success of a comedian in a stand-up comedy.

(Bit 2)

51 So, it's-it's rewarding for me and, uh, you know, I did it, and I got a selfie with Meryl Streep, and she kissed me after, it was... oh, my God, it was so exciting.

52 And then, um, Benedict Cumberbatch photobombed us, which was great, 'cause I'm such a Cumberbitch. (laughter) (pause)

53 And then after we did it, he whispered in my ear, (British accent):

"Well done." (laughter) (pause)

54 And I was so freaked out that I completely ignored bim, like.....(laughter)

55 But all these people, after all these white people were like, "Oh, that 


\section{was racist." \\ 56 "How dare you portray a Korean?" (laughter) (pause)}

Data on bit 2 shows how Margaret Cho uses punchlines repeatedly to create a humor situation. The punchline can be seen from utterances number 52 until 56, and the last utterance becomes the climax. In the beginning, Cho tells what happened on Golden Globe, that was doing a selfie with Meryl Streep. It became a joke when Benedict Cumberbatch photobombed them, and it made Cho liked a Cumberbitch. The audiences become laugh because Cho mentioned Cumberbatch into Cumberbitch. It is followed by how Cho demonstrated the British accent of Benedict Cumberbatch, followed by an act-out mimicking the movement ignoring the existence of someone on data 54. The climax of the punchline can be seen on the data 56 when all of the audiences are laugh when Margaret Cho as a South Korean woman portraying a North Korean General. The condition of South Korea and North Korea are not good. Several punchlines that Cho did make the audience laugh out loud.

\section{Closing}

Closing is the final part of a stand-up comedy structure. There are a variety of ways to close a stand-up comedy.

1063 Ob, my God!

1064 Thank you so much.

1065 Thank you so much for being here and being a part of this, I... Thank you. (crowd cheering)

1066 Thank you.

1067 Thank you so much, um, God, you know, it's like this is so amazing.

$1068 \mathrm{Ub}$, I feel like...

1069 I just want to, I want to sing you a song.

1070 I feel like it's just not enough.

1071 Like, it's not...

1072 Oh, my God I wish I had a band. (crowd cheering)

1073 (whoops) That was so exciting!

1074 We can all sing this together.

1075 It's gonna be really good.

1076 I'll show you, I'll show you.

1077 Oh, my God, so exciting!

1078 Thank you. (crowd cheers)

1079 Okay.

1080 S Got a fat pussy and a mean streak $\delta$ S Ride with me and you're rolling deep $\delta \delta$ Squirtyou like a spray tan $\$ \delta$ House you like a camper van $\delta \delta$ Notbing better, nothing wetter $\delta \delta$ Gonna get her, send a letter to my $\delta \delta$ Fat pussy $\delta$ Everybody! $\delta$ Fat pussy $\delta \delta$ Fat pussy, fat pussy $\delta \delta$ Fat pussy $\delta \delta$ Fat pussy, fat pussy $\delta \delta$ Fat pussy, yeah $\delta$ So good! (crowd cheering) Yes! $\delta$ Got a fat pussy $\delta \delta$ And hangers-on $\delta \delta$ Drum the drum you were banging on $\delta \delta$ Everyone 
always trying to $\delta \delta$ Put it in my vagina $\delta \delta$ Nothing better, nothing wetter $\delta \delta$ Gonna get her, send a letter $\delta \delta$ To my fat pussy $\delta$ S Come on, fat pussy $\delta \delta$ Fat pussy, fat pussy $\delta \delta$ Fat pussy, fat pussy $\delta \delta$ Fat pussy, fat pussy $\delta \delta$ My ass turns white, my tongue is tied $\delta \delta I^{\prime} m$ bonafide, please come $\delta \boldsymbol{S}$ Inside $\delta \boldsymbol{S}$ Swagger and a wink $\delta \delta$ Slide your blue into my pink. $\delta \delta$ Into my fat pussy $\delta \delta$ Come on, fat pussy $\delta \delta$ Fat pussy, fat pussy $\delta \delta$ Fat pussy, fat pussy $\delta \delta$ Fat pussy, fat pussy $\delta \delta M y$ ass turns white $\delta \delta$ Fat pussy $\delta \delta$ My tongue is tied $\delta \delta$ Fat pussy, fat pussy $\delta \delta$ I'm bona fide, please come inside $\delta \delta$ Fatpussy $\delta \delta$ Got a fat pussy and a mean streak. $\delta \delta$ Ride with me and you're $\delta \delta$ Fat pussy, fat pussy $\delta \delta$ Rolling deep $\delta \delta$ Fat pussy $\delta \delta$ Fat pussy $\delta \delta$ Oh... $\delta \delta$ Fat pussy, fat pussy $\delta \delta$ Fat pussy $\delta \delta$ Ob, ob $\delta \delta$ Fat pussy, fat pussy $\delta \delta$ Fat pussy $\delta \delta$ Fat... $\delta \delta$ Pussy. $\delta$ 1081 Thank you Jason Narducy, Jon Wurster, Sean Eden!

1082 Thank you so much!

1083 Good night! (crowd cheering)

Closing is an important part of the stand-up comedy structure. In this part, Margaret Cho uses comment on audience technique. Cho thanks to the audiences who have come to her stand-up comedy. Margaret Cho also presents a special song.

Margaret Cho ends the Psycho stand-up comedy as the only comedian in this stand-up comedy. The appreciation is also given to the musicians such as Jason Narducy, Jon Wurster, and Sean Eden. At the end of this stand-up comedy, Margaret Cho uses exclamatory closing by saying "good night!" to the audiences to end the stand-up comedy show.

According to the findings, the researcher found the result to answers the aim of this research. The structure of Psycho stand-up comedy is divided into three parts: the introduction, the core or the body, and the closing. There are 31 bits with a different topic in the body of Psycho stand-up comedy. In each bit, Margaret Cho raises four important parts of stand-up comedy; they are setup, punchline, transition (by fillers and surveys), and expanding successful jokes.

Here, the researcher can see that in creating a humor situation, Margaret Cho tends to use more punchlines to make the audience laugh. The repeated punchline can be found in each bit of the body in the Psycho standup comedy. Compare with the previous studies, Psycho stand-up comedy and other stand-up comedies from the earlier studies have similarities in certain parts. The researchers tried to find out the structure of the stand-up comedy. In general, every stand-up comedy has setup or build-up and followed by a punchline.

It is also different from the previous study that the researcher found from the findings. In the previous studies, one of the researchers found that in the Kill the Messenger stand-up comedy by Christ Rock, it has several structures and patterns: one-liners, questions and answers, simple structures, and complex structure. While another researcher found that the structure of Malaysian ethnic and political stand-up comedies have three standard structures: build-up, pivot, punchline, and the use of build-up is more in the 
Malaysian ethnic stand-up comedy rather than in the Malaysian political stand-up comedy. While in the Psycho stand-up comedy, the researcher found that there are three parts of this stand-up comedy: the introduction, the body consists of setup, punchline, transition (by fillers and surveys), and expanding successful jokes, and the closing. However, Cho tends to use punchline repeatedly or expanding successful jokes as the characteristics of Psycho stand-up comedy.

The other research in Indonesian stand-up comedy from comedians like Raditya Dika, Ryan Adryandhi, and Abdel Achrian found that the opening and the closing of this stand-up comedy have the important part and it has the similarities with Rutter's (1997) pattern. While in Psycho stand-up comedy, the researcher tried to combine the structure of humor by Rutter (1997) and Scarpetta \& Spagnolli (2009). Here the researcher found that the Psycho stand-up comedy has the similarities with Rutter's (1997) pattern and Scarpetta \& Spagnolli's (2009) pattern.

\section{CONCLUSION}

According to the result of the data analysis, the structure of the Psycho stand-up comedy conveyed by Margaret Cho has a structure following the theory that is presented by Rutter (1997) and Scarpetta \& Spagnolli (2009). In general, the structure is divided into three parts: the introduction, the core (the body), and the closing. The part of the body of the Psycho stand-up comedy consists of 31 bits with different topics in each of them. In each bit, Margaret Cho always raises four important parts: setup, punchline, transition consisting of fillers and surveys, as well as followed by expanding successful jokes. Margaret Cho's success in creating humor situation is not detached from her ability to develop successful jokes. Almost every bit is done by punchline repeatedly to make the audiences laugh.

This research is a small part of research on female stand-up comedy in the field of linguistics. Therefore, it can still be developed by using other linguistic disciplines. Other researchers can examine more closely related to the female stand-up comedy in critical discourse analysis, translation studies, or compare this Psycho stand-up comedy with another female stand-up comedy to find out the characteristic of each stand-up comedy.

\section{REFERENCES}

Afidah, L., \& Wahyudi, R. (2014). How It Starts And Ends: A Study Of Indonesian Stand-Up Comedy. Jurnal Pendidikan Babasa Dan Sastra, 14. https://doi.org/10.17509/bs_jpbsp.v14i2.716

Attardo, S. (2017). The routledge handbook of language and humor. In The Routledge Handbook of Language and Humor. New York: Routledge. 
https://doi.org/10.4324/9781315731162

Chun, E. (2004). Ideologies of legitimate mockery: Margaret Cho's revoicings of mock Asian. Pragmatics, 14, 263-289. https://doi.org/10.1075/prag.14.2-3.10chu

Creswell, J. W. (2014). Research design: Qualitative, quantitative, and mixed methods approaches. 4th Edition. In SAGE Publication. https://doi.org/10.1007/s13398-014-0173-7.2

Dean, G. (2000). Step by Step to Stand-Up Comedy. New Hampshire: Heinemann.

Double, O. (2014). Getting the Joke: The Inner Workings of Stand-up Comedy. London: Bloomsbury.

Menard, B. (2017). Margaret Cho Psycho - Full Movie. https://www.youtube.com/watch?v=_VfOZCm92Yg

Mulyana. (2005). Kajian Wacana: Teori, Metode \& Aplikasi Prinsip-Prinsip Analisis Wacana. Yogyakarta: Penerbit Tiara Wacana.

Onn, C. T. (2018). A Comparison of Malaysian Ethnic and Political Stand-up Comedies' Text Structures and Use of Politeness Strategies. International Journal of Applied Linguistics and English Literature, 7, 182-190. https://doi.org/10.7575/aiac.ijalel.v.7n.7p.182

Ross, A. (2005). The language of humour. In The Language of Humour. New York: Routledge. https://doi.org/10.4324/9780203984567

Rutter, J. (1997). Stand-up as Interaction: Performance and Audience in Comedy Venues. University of Salford.

Rutter, J. (2000). The stand-up introduction sequence: Comparing comedy compères. Journal of Pragmatics, 32(4), 463-483. https://doi.org/10.1016/s0378-2166(99)00059-4

Scarpetta, F., \& Spagnolli, A. (2009). The Interactional Context of Humor in Stand-Up Comedy. Research on Language \& Social Interaction, 42(3), 210 230. https://doi.org/10.1080/08351810903089159

Sobur, A. (2006). Analisis Teks Media: Suatu Pengantar untuk Analisis Wacana, Analisis Semiotika, dan Analisis Framming. Bandung: PT. Remaja Rosdakarya.

Triandana, A. (2014). Analisis Wacana Humor dalam Film Kill the Messenger (Studi Kasus Stand-Up Comedy Chris Rock). In Tesis S2 Linguistik. Universitas Gadjah Mada.

Yule, G. (1996). Pragmatics. In Pragmatic. Oxford: Oxford University Press. 